\title{
Effect of Lactobacillus plantarum Inoculation on Chemical Composition, Fermentation, and Bacterial Community Composition of Ensiled Sweet Corn Whole Plant or Stover
}

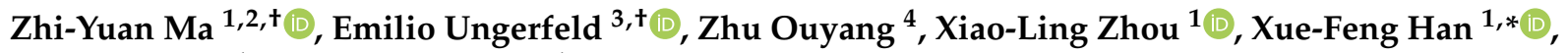 \\ Yan-Qin Zeng ${ }^{1}$ and Zhi-Liang Tan ${ }^{1}$
}

1 CAS Key Laboratory for Agro-Ecological Processes in Subtropical Region, National Engineering Laboratory for Pollution Control and Waste Utilization in Livestock and Poultry Production, Institute of Subtropical Agriculture, Chinese Academy of Sciences, Changsha 410125, China; mzy@lzu.edu.cn (Z.-Y.M.); zxldky@126.com (X.-L.Z.); ashwy70@163.com (Y.-Q.Z.); zltan@isa.ac.cn (Z.-L.T.)

2 College of Pastoral Agriculture Science and Technology, Lanzhou University, Lanzhou 730020, China

3 Centro Regional de Investigación Carillanca, Instituto de Investigaciones Agropecuarias INIA, Temuco 4880000, Chile; emilio.ungerfeld@inia.cl

4 Institute of Geographic Sciences and Natural Resources Research, Chinese Academy of Sciences, Beijing 100101, China; ouyz@igsnrr.ac.cn

* Correspondence: xfhan@isa.ac.cn; Tel.: +86-7314619702

+ These authors have contributed equally to this work.

\section{check for} updates

Citation: Ma, Z.-Y.; Ungerfeld, E.; Ouyang, Z.; Zhou, X.-L.; Han, X.-F.; Zeng, Y.-Q.; Tan, Z.-L. Effect of Lactobacillus plantarum Inoculation on Chemical Composition, Fermentation, and Bacterial Community Composition of Ensiled Sweet Corn Whole Plant or Stover. Fermentation 2022, 8, 24 . https://doi.org/10.3390/ fermentation 8010024

Academic Editor: Qing Zhang

Received: 16 December 2021

Accepted: 5 January 2022

Published: 10 January 2022

Publisher's Note: MDPI stays neutral with regard to jurisdictional claims in published maps and institutional affiliations.

Copyright: (c) 2022 by the authors. Licensee MDPI, Basel, Switzerland. This article is an open access article distributed under the terms and conditions of the Creative Commons Attribution (CC BY) license (https:// creativecommons.org/licenses/by/ $4.0 /)$.

\begin{abstract}
Sweet corn is a feed resource with a high content of water-soluble carbohydrates (WSC) available for ruminant production. This study was conducted to investigate the effect of inoculation with Lactobacillus plantarum on fermentation and nutritional quality of sweet corn silage. Sweet corn whole plant (WP) and sweet corn stover (CS) were ensiled in mini silos with or without inoculation of L. plantarum. Proximate composition and fermentation variables, and composition of the bacterial community, were evaluated before ensiling and at the end of the first, second, and third month after ensiling. There was fiber degradation in CS silage after three months of ensilage, but not in WP silage. Inoculation of WP silage, but not of CS silage, with L. plantarum, increased starch content. The relative abundance of genus Lactobacillus was increased by inoculation with L. plantarum by $14.2 \%$ and $82.2 \%$ in WP and CS silage, respectively. Inoculation with L. plantarum was not necessary to achieve adequate fermentation of either WP or CS silage, as the abundance of native lactic acid bacteria in both materials seemed suitable for adequate fermentation. That said, increased starch content in WP resulting from inoculation with L. plantarum can increase the nutritive value of WP for ruminants.
\end{abstract}

Keywords: silage; Lactobacillus plantarum; sweet corn; fermentation; bacterial community

\section{Introduction}

Mutant genes present in sweet corn prevent the formation of starch from reducing sugars and sucrose during the milk-ripe stage [1]. As a result, sweet corn can have 10 to 20 times as much water-soluble carbohydrate (WSC) content than regular corn [2]. Sweet corn kernel is mainly consumed as human food [3]. At present, about 1.4 million hectares of sweet corn are grown annually worldwide [4]. Cultivation of sweet corn has also been increasing in China in recent years [5]. Its growth area has increased from less than 10,000 hectares in 2000 to 400,000 hectares in 2018. In particular, about 70\% sweet corn in China is grown in subtropical areas [5], where the temperature is optimal for sugar accumulation in kernels [6] and other parts of the plant [7].

Sweet corn stover (CS) is obtained after harvesting the ears of whole plant corn (WP), representing about $75 \%$ of total dry matter of the plant [8]. Sweet corn stover is thus a resource available in large amounts, which can be used in ruminant feeding. The Chinese Guangdong province alone, for instance, produces about 10-million tons of sweet corn 
stover annually [5]. Using whole sweet corn plant as an animal feed is also of interest to increase the amount of plant biomass harvested [9]. Furthermore, harvesting the whole sweet corn plant for feed including kernels also enhances its nutritive value compared to stover alone due to its high content of rapidly fermentable carbohydrates [10], which is important for animal categories with high nutrients requirements such as high-yielding dairy cows in early lactation [11].

Both sweet corn stover and whole plant can be ensiled and fed to ruminants. It is therefore important to study the ensiling processes of sweet corn stover and whole plant, and to seek ways to improve fermentation and nutritive value of the resulting silages. Ensiling plant substrates with excess moisture can result in the loss nutrients such as WSC, hemicellulose, and cellulose [12]. Sweet corn is typically higher in moisture than regular corn [3]. Kurle et al. [13] reported that sweet corn was more susceptible to spoilage than regular corn during the ensiling process. The unwanted fermentation in sweet corn silages include activity from Clostridium and yeast, which might be caused by excessive WSC [14]. An alternative to improve the ensiling process of sweet corn and avoid nutrient losses is to enhance the amount and activity of lactic acid bacteria (LAB) through the inoculation of Lactobacillus plantarum as a live added lactic acid bacterium $[15,16]$. To our knowledge, the effects of inoculation with LAB on fermentation and the bacterial community composition of ensiled sweet corn have not been investigated. We hypothesized that inoculation with L. plantarum would improve fermentation and nutritional quality of CS and WP silages, as reflected in the evolution of $\mathrm{pH}$, organic compounds, proximate composition, and the bacterial community composition. Our objective was to investigate the effects of inoculating L. plantarum on the fermentation and microbial composition of ensiled CS and WP as silage substrates available in subtropical China for ruminant feeding.

\section{Materials and Methods}

\subsection{Forage Harvest, Ensiling Conditions, and Sampling}

Sweet corn cultivar Huatian $1 \mathrm{WP}$ and CS were harvested on the same day (20 days after silking) at a stubble height of 15 to $20 \mathrm{~cm}$, and chopped with a ZC-6 ensilage cutter (Yiyang Agriculture Machinery Factory, Qufu, China) to about $3 \mathrm{~cm}$. Stover was harvested after first harvesting apart the ears. We randomly selected 24 10-kilogram portions of each material for ensiling in individual mini-silos. Half of the portions of each forage were sprayed with a $50 \mathrm{~mL}$ suspension of $10^{7} \mathrm{CFU} / \mathrm{mL}$ Lactobacillus plantarum (Yaxin biotec. Taiwan, China) at a dosage of $10^{5} \mathrm{CFU} / \mathrm{g}$ of fresh forage, as recommended by the manufacturer (Inoculation, I+), while the other half of the portions received an equal volume of distilled water (Control, I-). The substrates were packed and compressed manually into polyvinyl chloride mini-silos (5 L, Yifang Plastic Mfg. Co., Ltd., Dongguan, China), and hermetically sealed with a screw top. About $4 \mathrm{~kg}$ fresh forages were filled in mini silos. A total of 48 silos, with 12 silos for each combination of substrate and presence or absence of inoculant, were stored at ambient temperature (ranging from 27 to $38^{\circ} \mathrm{C}$ ). Four fresh samples of chopped CS and WP obtained before inoculation and ensilage were stored at $-80^{\circ} \mathrm{C}$. These initial forage samples were then pooled per each ensilaged substrate for subsequent analysis of proximate composition and bacterial community initially present, and designated as samples from 0 month after ensiling. At the end of the first, second, and third months after ensiling, 4 mini-silos per each of the four combinations of ensiled substrates and inoculation were opened, the upper $2 \mathrm{~cm}$ layer was discarded, and the remaining substrate mixed thoroughly. About $100 \mathrm{~g}$ sub-samples were obtained through quartering and crushed for two minutes into 4-8 $\mathrm{mm}$ particles with a high-speed grinding machine (Xichu Co., Shanghai, China). Twenty-five grams of crushed samples were macerated in $225 \mathrm{~mL}$ distilled water with a stomacher and shaken at $150 \mathrm{rpm}$ and $4{ }^{\circ} \mathrm{C}$ for $24 \mathrm{~h}$. Water extracts were filtered using two layers of Whatman filter paper (pore size of $11 \mu \mathrm{m}$, Xinhua Co., Hangzhou, China). The filtered liquid was acidified with 25\% $(v / v)$ meta-phosphoric acid and frozen at $-20{ }^{\circ} \mathrm{C}$ for subsequent analysis of concentrations 
of ammonium $\left(\mathrm{NH}_{4}{ }^{+}\right)$, lactic acid, and volatile fatty acids. Dry matter loss could not be calculated as the initial mass of silage was not recorded.

\section{2. $\mathrm{pH}$ Determination}

$\mathrm{pH}$ was measured according to the recommended procedure by Bernardes et al. [17]. In brief, A second $25 \mathrm{~g}$ portion of crushed samples were macerated in $225 \mathrm{~mL}$ distilled water and blended for $30 \mathrm{~s}$, and $\mathrm{pH}$ determined with a portable electrode $\mathrm{pH}$ meter (Starter 300, Ohaus Instruments Co., Ltd., Shanghai, China).

\subsection{Determination of Ammonia Nitrogen, Lactic Acid, Volatile Fatty Acids, and Ethanol}

Samples were thawed at room temperature and centrifuged at $15,000 \times g$ and $4{ }^{\circ} \mathrm{C}$ for $10 \mathrm{~min}$. The supernatant was filtered through a $0.22 \mu \mathrm{m}$ membrane into a glass vial for organic acids and $\mathrm{NH}_{4}{ }^{+}$analysis. The concentrations of total and individual volatile fatty acids (VFA) and ethanol were analyzed following the procedures described by Playne [18]. Lactic acid was analyzed by high performance liquid chromatography (Agilent HPLC 1290, Agilent Inc., Santa Clara, CA, USA), as described by Zhou et al. [14]. Ammonium concentration was determined using the phenol-hypochlorite procedure according to Chen et al. (2016).

\subsection{Proximate Composition}

Proximate composition of substrates before ensiling, and of silages after 1, 2, or 3 months of ensilage was analyzed. Contents of dry matter (method 934.01), total ash (method 942.05), ether extract (method 7.045), and crude protein (method 990.03) were determined according to AOAC [19]. The NDF and ADF contents were determined with a Fibretherm analyzer (C. Gerhar, Königswinter, Germany) with a heat-stable amylase and expressed inclusive of residual ash following the procedures of Van Soest et al. [20]. The starch content was determined after pre-extraction with $80 \%$ ethanol through measuring glucose released from starch hydrolysis with an $\alpha$-amylase (Sigma Chemical Co., St. Louis, MO, USA) according to Karthner et al. [21]. Contents of WSC were measured according to the anthraquinone colorimetric reaction with furfural or hydroxymethyl furfural, which were produced by dehydration reaction with concentrated sulfuric acid according to Zahiroddini et al. [22].

\subsection{DNA Extraction, $q P C R$, and Pyrosequencing}

Thirty-gram portions of crushed samples were frozen at $-80{ }^{\circ} \mathrm{C}$, lyophilized, and ground to about $1 \mathrm{~mm}$. Two hundred and fifty-milligram samples were used for DNA extraction using the QIAamp fast DNA stool mini kit (Qiagen, Hilden, Germany) according to the manufacturer instructions. The concentration and purity of total DNA were measured using a ND-2000 spectrophotometer (NanoDrop Technologies, Wilmington, NC, USA). All microbial DNA samples were diluted to $10 \mathrm{ng} / \mu \mathrm{L}$ for $\mathrm{qPCR}$ analysis.

Total bacterial abundance was quantified by qPCR as copies of $16 \mathrm{~S}$ rRNA genes in a LightCycler ${ }^{\mathrm{TM}} 480$ (Roche Molecular Systems, Inc., Pleasanton, CA, USA). Forward $(\mathrm{F})$ and reverse primers (R) were: 5'-CGGCAACGAGCGCAACCC $-3^{\prime}(\mathrm{F})$ and 5'-CCATTGTAGCACGTGTGTAGCC (R) [23]. Ten nanogram DNA samples were analyzed in triplicate in $10 \mu \mathrm{L}$ amplification reactions consisting of $1 \times$ qPCR SuperMix (Transgen, Beijing, China) and 0.1 $\mathrm{M}$ each primer (Sangon Biotech, Shanghai, China). Five-gradient dilutions of plasmid DNA including target 16S rRNA genes achieved in our previous work [24] were used for standard curves. The qPCR procedure consisted of an initial cycle at $94{ }^{\circ} \mathrm{C}$ for $30 \mathrm{~s}, 40$ cycles of $94{ }^{\circ} \mathrm{C}$ for $5 \mathrm{~s}, 60{ }^{\circ} \mathrm{C}$ for $15 \mathrm{~s}$, and $72{ }^{\circ} \mathrm{C}$ for $10 \mathrm{~s}$ [23]. Final absolute copies of target $16 \mathrm{~S}$ rRNA genes were estimated by relating the $C t$ value to standard curves and were expressed as copies/g of lyophilized samples ( $\log 10$ transformed).

The relative abundance of bacterial genera in fresh forages and silages was assessed by amplicon pyrosequencing. The 16s rRNA gene V3-V4 hypervariable region of bacterial ge- 
nomic DNA was used for PCR amplification with the primers 5'-CCTAYGGGRBGCASCAG$3^{\prime}$ (341F) and 5'-GGACTACNNGGGTATCTAAT-3' (806R) [25]. PCR reactions were performed in triplicate in a $20 \mu \mathrm{L}$ mixture containing $0.8 \mu \mathrm{L}$ of each primer $(10 \mu \mathrm{M}), 10 \mathrm{ng}$ of template DNA, $2 \mu \mathrm{L} 2.5 \mathrm{mM}$ dNTPs, $0.4 \mu \mathrm{L}$ of FastPfu primer (Transgen, Beijing, China), and $4 \mu \mathrm{L} 5 \times$ FastPfu Buffer (Transgen, Beijing, China). The thermal cycling programing was performed as follows: 3 min for an initial denaturation step at $95{ }^{\circ} \mathrm{C}$, 27 cycles of denaturation at $95{ }^{\circ} \mathrm{C}$ for $30 \mathrm{~s}$, annealing at $55{ }^{\circ} \mathrm{C}$ for $30 \mathrm{~s}$, and elongation at $72{ }^{\circ} \mathrm{C}$ for $45 \mathrm{~s}$, and a final extension at $72{ }^{\circ} \mathrm{C}$ for $10 \mathrm{~min}$. The PCR products were excised from $2 \%$ agarose gels and purified using a QIAquick Gel extraction kit (Qiagen, Hilden, Germany). Amplicons from each reaction mixture were quantified fluorometrically, normalized and pooled at equimolar ratios based on the concentration of each amplicon. Amplicons were sequenced with the Illumina MiSeq PE300 platform at the Novagen Technology, Beijing, China. Quality control of the sequence reads was performed using MOTHUR v.1.35 [26] following the protocol described by Kozich et al. [27]. The high-quality reads were clustered into operational taxonomic units (OTUs) at a 97\% similarity and representative sequences were defined by abundance of each OTU. Taxonomy analysis was conducted using the RDP classifier v.11.1 with a minimum support threshold of $80 \%$ [28] against the SILVA database v.128 [29].

\subsection{Statistical Analyses}

The initial models for all response variables included the three main effects and double interactions:

$$
\begin{aligned}
\text { Response }_{\mathrm{ijk}} & =\text { substrate }_{\mathrm{i}}+\text { inoculation }_{\mathrm{j}}+\text { month }_{\mathrm{k}}+\text { substrate } \times \text { month }_{\mathrm{ik}}+\text { substrate } \\
& \times \text { inoculation }_{\mathrm{ij}}+\text { month } \times \text { inoculation }_{\mathrm{jk}}+\text { error }_{\mathrm{ijk}}
\end{aligned}
$$

Triple interactions were not included because they were not central to the hypothesis being tested and in order to diminish the possibility of overfitting models by adding an extra parameter.

When significant $(p<0.05)$ interactions were present, one main effect was compared across each level of the interacting effect. Non-significant $(p \geq 0.05)$ interactions were eliminated and the reduced models were re-fitted. All regressions were fitted using the $\operatorname{lm}($ ) function of $R 3.4$ software (R Core Team, https:/ / www.R-project.org/ (accessed on 11 December 2018)).

\section{Results}

\subsection{Proximate Composition of Forages and Silages}

At harvest, proximate composition of WP was: $30.9 \% \mathrm{DM}$, and on a DM basis: 7.80\% CP, 43.8\% NDF, 28.7\% ADF, 30.7\% starch, 15.3\% WSC, and 2.26\% EE. Proximate composition of CS at harvest was: $23.1 \%$ DM, and on a DM basis: $7.23 \% \mathrm{CP}, 66.8 \% \mathrm{NDF}$, 42.6\% ADF, $8.08 \%$ starch, $13.4 \%$ WSC, and $1.70 \%$ EE.

Contents of DM, OM, and starch were higher $(p<0.001$, Figure 1$)$, while NDF and ADF were lower $(p<0.001)$ in WP than in CS silage. There was an interaction between month after ensiling and inoculation on DM and OM contents $(p \leq 0.01)$, with higher $\mathrm{DM}$ and $\mathrm{OM}$ contents in inoculated compared with non-inoculated silage at the end of the third month after ensiling $(p<0.001)$, and no differences at the end of the first and second months after ensiling $(p \geq 0.08)$. Substrate and month after ensiling interacted on NDF and ADF contents $(p<0.001)$, with NDF and ADF of CS silage decreasing in the third month $(p<0.001)$, whereas there were no changes in WP silage $(p \geq 0.11)$. There were interactions between substrate and inoculation on starch and CP content $(p \leq 0.04)$. Inoculation decreased starch content in CS silage $(p=0.004)$ but increased starch content in WP silage $(p=0.001)$. Content of CP was increased by inoculation in WP silage $(p=0.015)$ but not in CS silage $(p=0.86)$. Content of EE decreased after 1 month of ensiling in CS silage only $(p<0.001$; interaction $S \times M, p<0.001)$. All dual interactions between substrate, month, and inoculation on WSC content of silage were significant $(p<0.001)$. There was a 
tendency for WSC contents of both substrates to decrease in the first and the third months after ensiling $(p \leq 0.08)$. Inoculation increased WSC in CS silage $(p<0.001)$ but not in WP silage $(p=0.45)$. With both substrates, inoculation increased WSC content at the end of first and third months after ensiling $(p \leq 0.04)$, but not by the end of the second month after ensiling $(p=0.16)$.

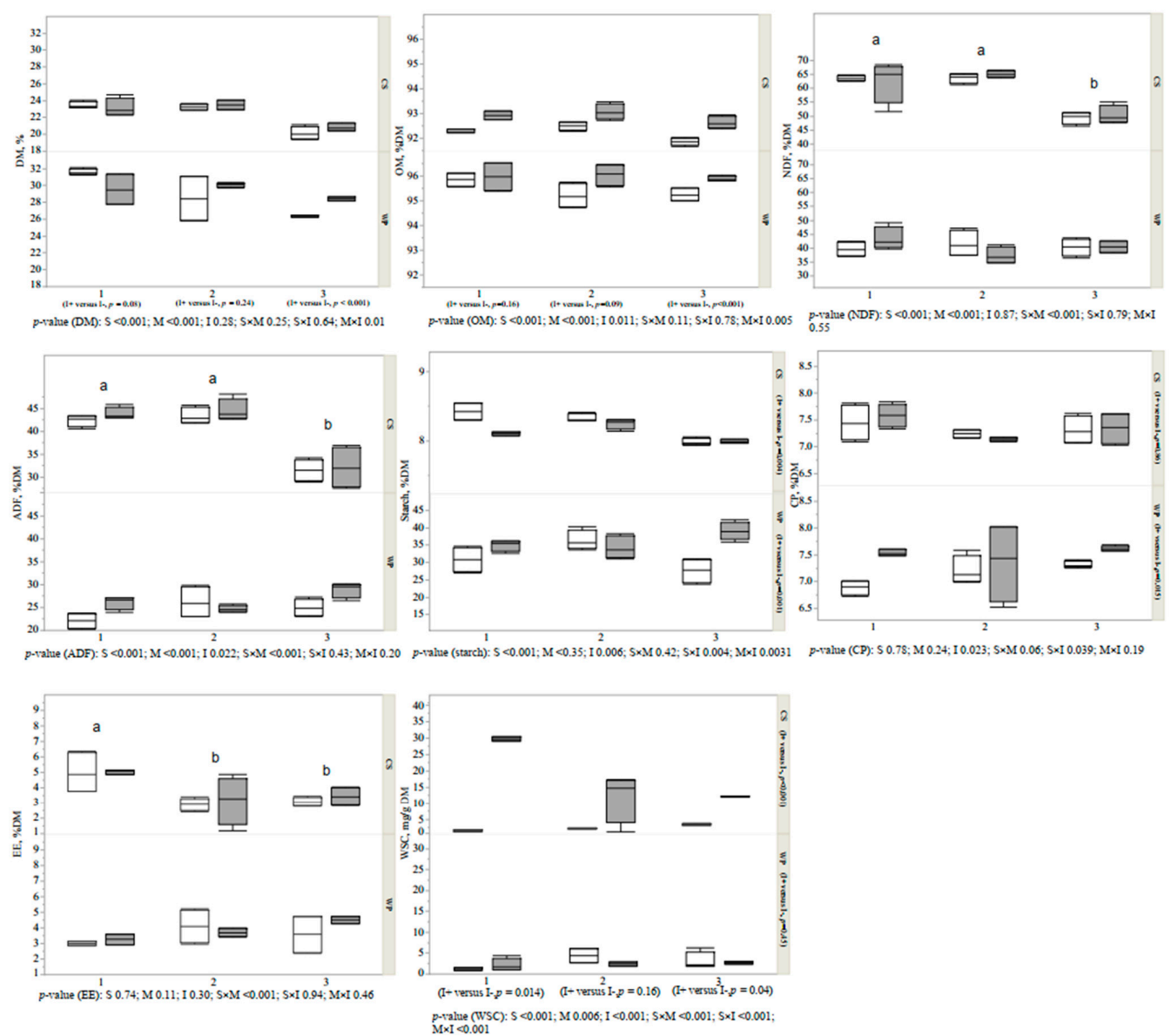

Figure 1. Effect of substrate, time after ensiling, and inoculation of Lactobacillus plantarum on chemical composition of silage $(n=4)$. CS, sweet corn stover; WP, sweet corn whole plant. Sampling time points (months after ensiling) are scattered along the $x$ axis. Boxes filled in gray indicate inoculation with Lactobacillus plantarum. Horizontal lines inside the boxes indicate the median, upper and lower lines of boxes indicate upper and lower quartiles, respectively, and whiskers indicate the maximum and the minimum. $p$-values for the following effects are provided in legends below the graph: $\mathrm{M}$, Months after ensiling; $\mathrm{S}$, substrate; I-, not inoculated; I+, inoculated; $\mathrm{S} \times \mathrm{M}$; interaction between substrate and month; $\mathrm{S} \times \mathrm{I}$; interaction between substrate and inoculation; $\mathrm{M} \times \mathrm{I}$; interaction between month and inoculation. DM, dry matter; OM, organic matter (100\% minus ash content); NDF, neutral detergent fiber; $\mathrm{ADF}$, acid detergent fiber; $\mathrm{CP}$, crude protein; EE, ether extract; WSC, water soluble carbohydrates. ${ }^{\mathrm{ab}}$ Unlike-lower case letters within a substrate differ $(p<0.05)$.

\subsection{Fermentation Variables}

There was an interaction between substrate and inoculation on $\mathrm{pH}(p<0.001$, Figure 2), with $\mathrm{pH}$ being decreased by inoculation in CS silage $(p=0.016)$ but not in WP silage $(p=0.38)$. There was a tendency for a decrease in $\mathrm{NH}_{4}{ }^{+}$concentration in inoculated silages at the third month ensiling ( $p=0.07$; interaction $\mathrm{M} \times \mathrm{I}, p=0.07)$. Lactic acid concentration was not influenced by inoculation $(p=0.28)$, regardless of substrate (interaction $S \times I, p=0.22$ ). Lactic acid concentration of WP silage increased in the third month after ensiling $(p=0.003)$, whereas it did not change in CS silage $(p \geq 0.38$; interaction $\mathrm{S} \times \mathrm{M})$. Ethanol concentration tended to increase in the third month of ensilage in inoculated silages $(p=0.004$; interaction 
$\mathrm{M} \times \mathrm{I}, p=0.07)$, and in WP silage $(p=0.10$; interaction $\mathrm{S} \times \mathrm{M}, p=0.09)$. There were interactions between substrate and month after ensiling on total VFA, acetic acid, and propionic acid concentrations $(p \leq 0.028)$. Total VFA and acetic acid concentration in CS silage increased in the second month after ensiling and decreased in the third month $(p<0.001)$, whilst in WP silage total VFA and acetic acid concentration increased at the end of the third month after ensiling compared with the end of the first month after ensiling $(p<0.001)$. Month after ensiling and inoculation also interacted on acetic acid concentration $(p<0.001)$, with lower acetic acid concentration in inoculated silages at the end of the first and third month after ensiling $(p \leq 0.034)$, but not at the end of the second month after ensiling ( $p=0.83$ ). Butyrate concentration was not affected by substrate, inoculation, month, or their interactions $(p \geq 0.36)$.

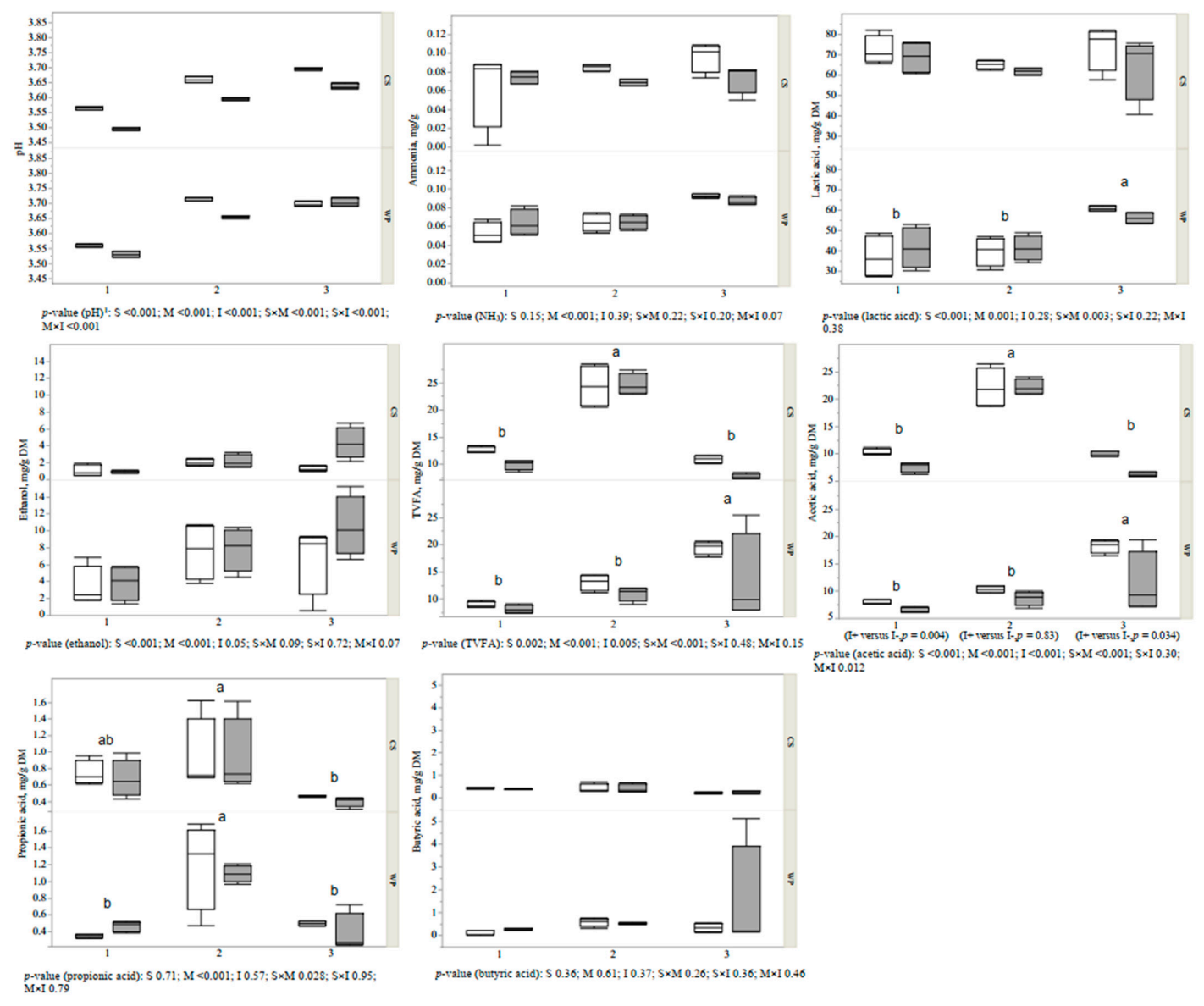

Figure 2. Effects of substrate, time after ensiling, and inoculation of Lactobacillus plantarum on fermentation variables of silage $(n=4)$. CS, sweet corn stover; WP, sweet corn whole plant. Sampling time points (months after ensiling) are scattered along the $x$ axis. Boxes filled in gray indicate inoculation with Lactobacillus plantarum. Horizontal lines inside the boxes indicate the median, upper and lower lines of boxes indicate upper and lower quartiles, respectively, and whiskers indicate the maximum and the minimum. $p$-values for the following effects are provided in legends below the graph: M, Months after ensiling; S, substrate; I-, not inoculated; I+, inoculated; $\mathrm{S} \times \mathrm{M}$; interaction between substrate and month; $\mathrm{S} \times \mathrm{I}$; interaction between substrate and inoculation; $\mathrm{M} \times \mathrm{I}$; interaction between month and inoculation. ${ }^{\mathrm{ab}}$ Unlike-lower case letters within a substrate differ $(p<0.05)$.

\subsection{Microbial Community Composition}

There were no interactions with regards to total bacterial $16 \mathrm{~S}$ rRNA gene copies ( $p \geq 0.12$, Figure 3). Total bacterial $16 \mathrm{~S}$ rRNA gene copies were higher at the end of the first month after ensiling than at the end of second and third month after ensiling $(p<0.001)$. 
There was no effect of inoculating with L. plantarum on total bacterial $16 \mathrm{~S}$ rRNA gene copies $(p=0.83)$.

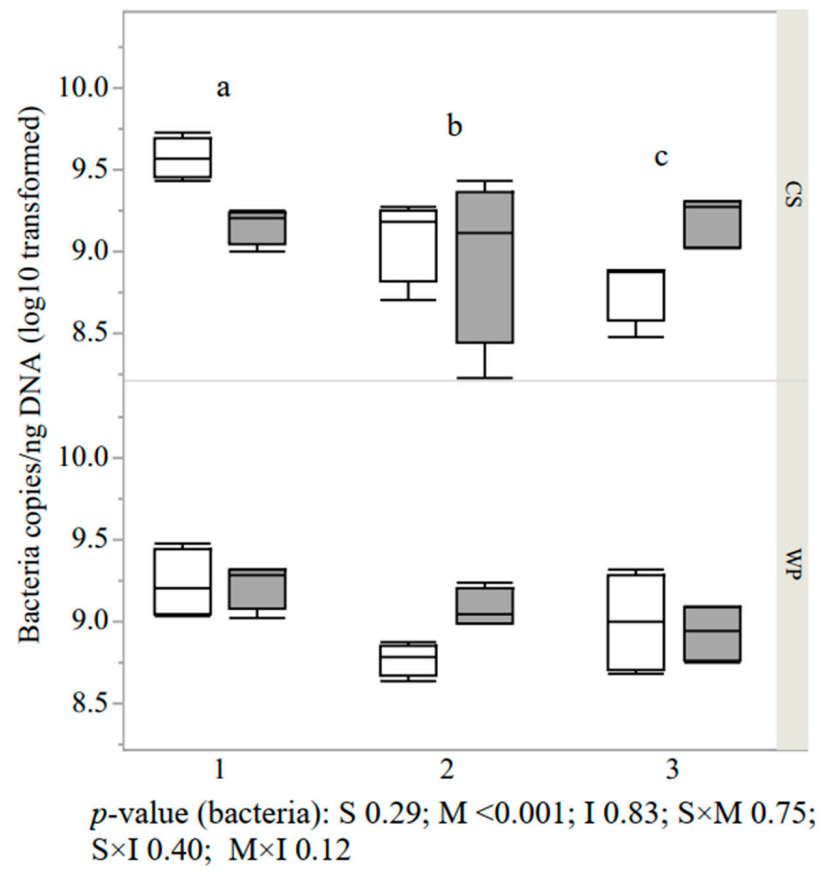

Figure 3. Effects of substrate, time after ensiling, and inoculation of Lactobacillus plantarum on total bacterial 16S rRNA gene copies in silage $(n=4)$. Substrates are shown in different panels. CS, sweet corn stover; WP, sweet corn whole plant. Sampling time points (months after ensiling) are scattered along the $x$ axis. Inoculation with Lactobacillus plantarum is indicated with gray filling in the box plots. $p$-values for the following effects are provided in legends below the graph: M, Months after ensiling; $\mathrm{S}$, substrate; I, inoculation; $\mathrm{S} \times \mathrm{M}$, interaction between substrate and month; $\mathrm{S} \times \mathrm{I}$; interaction between substrate and inoculation; $\mathrm{M} \times \mathrm{I}$; interaction between month and inoculation. ${ }^{\text {abc }}$ Unlike letters indicates differences $(p<0.05)$ among time points after ensiling.

Bacterial genera dominating fresh CS and WP forages before ensiling were Pseudomonas, Klebsiella, Pantoea, Enterobacter, and Lactococcus (Figure 4). Lactobacillus accounted for only $0.4 \%$ of total bacterial amplicons in both CS and WP before ensiling.

The Shannon bacterial diversity index at the genus level was higher in WP silage than in CS silage ( $p<0.001$, Figure 5). Inoculation resulted in lower Shannon index regardless of the ensiling substrate or month $(p=0.004$; interaction $\mathrm{S} \times \mathrm{I}, p=0.12$; interaction $\mathrm{M} \times \mathrm{I}$, $p=0.13)$. The Shannon diversity index of Lactobacillus OTUs was consistently lower in the inoculated silages $(p \leq 0.003)$.

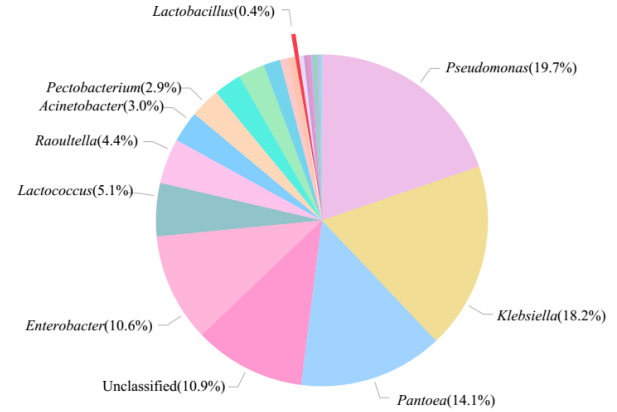

CS

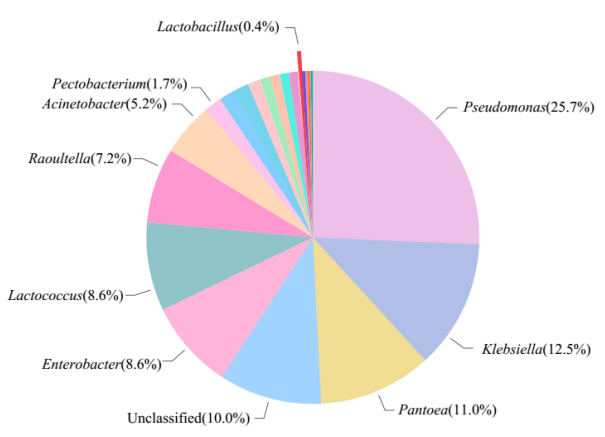

WP

Figure 4. Bacterial communities at genus level of sweet corn stover (CS) and whole plant (WP) before ensiling. Top 9 genera and Lactobacillus are labeled and their relative abundance is shown in brackets. 

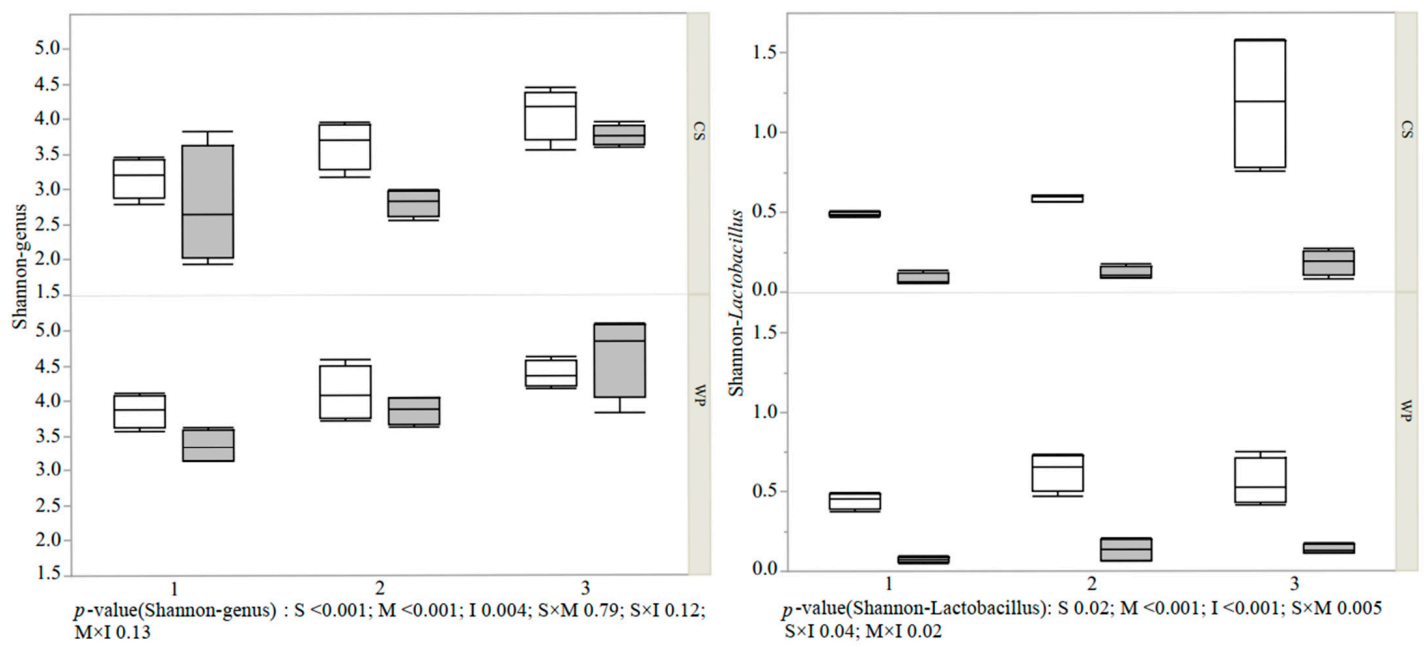

Figure 5. Effects of substrate, ensiling time, and inoculation of Lactobacillus plantarum on the Shannon index of bacterial diversity at the genus level and of the Lactobacillus genus diversity at OTU level $(\mathrm{n}=4)$. Substrates are shown in panels. CS, sweet corn stover; WP, sweet corn whole plant. Sampling time points (months after ensiling) are scattered along the $x$ axis. Inoculation with Lactobacillus plantarum is indicated with gray filling in the box plots. $p$ values for the following effects are provided in legends below the graph: M, Months after ensil-ing; S, substrate; I, inoculation; $\mathrm{S} \times \mathrm{M}$; interaction between substrate and month; $\mathrm{S} \times \mathrm{I}$; interaction between substrate and inoculation; $\mathrm{M} \times \mathrm{I}$; interaction between month and inoculation.

Inoculation resulted in higher abundance of genus Lactobacillus in WP silage $(p=0.01)$ but not in CS silage ( $p=0.63$; interaction $S \times \mathrm{I}, p<0.001$; Figure 6). Inoculation increased the abundance of Lactobacillus at the end of first month after ensiling $(p=0.014)$, and did not affect it at the second and third month of ensilage ( $p \geq 0.11$; interaction $\mathrm{M} \times \mathrm{I}, p=0.09)$. Pseudomonas increased after ensiling and was at its highest abundance at the end of the third month after ensiling in CS silage $(p<0.001)$, whilst it reached its highest abundance in month 2 after ensiling in WP silage ( $p=0.03$; interaction $\mathrm{S} \times \mathrm{M}, p=0.005)$. Inoculation increased Pseudomonas in CS silage $(p=0.05)$ but not in WP silage $(p=0.41$; interaction $\mathrm{S} \times \mathrm{I}$, $p=0.04)$. Abundance of Klebsiella was higher in WP silage than in CS silage $(p<0.001)$, but was not influenced by inoculation regardless of ensiling month ( $p \geq 0.19$; interaction $\mathrm{M} \times \mathrm{I}$, $p=0.28)$. Inoculation did not affect Klebsiella in CS silage $(p=0.74)$ but decreased Klebsiella in WP silage ( $p=0.004$; interaction $\mathrm{S} \times \mathrm{I}, p=0.06$ ). Inoculation had no effect on Enterobacter in CS silage ( $p=0.57$ ) but decreased Enterobacter in WP silage ( $p=0.01$; interaction $\mathrm{S} \times \mathrm{I}$, $p=0.01$ ). Inoculation decreased Enterobacter at the end of the first and second month after ensiling ( $p \leq 0.045)$, but had no effect on Enterobacter at the end of the third month after ensiling ( $p=0.65$; interaction $\mathrm{M} \times \mathrm{I}, p=0.01)$. Acinetobacter reached its highest abundance at the end of the second month after ensiling in CS silage $(p<0.001)$ but not in WP silage $(p=0.57$; interaction $\mathrm{S} \times \mathrm{M}, p<0.001)$. Panteoea reached its highest abundance at the end of the first month after ensiling in CS silage $(p=0.05)$, and at the end of the third month after ensiling in WP silage ( $p<0.001$; interaction $\mathrm{S} \times \mathrm{M}, p<0.001)$. Inoculation decreased Panteoea in CS silage ( $p<0.001)$ but not in WP silage $(p=0.11$; interaction $\mathrm{S} \times \mathrm{I}, p=0.002)$. Inoculation decreased Panteoea at the end of the first month after ensiling $(p=0.05)$, but had no influence thereafter ( $p \geq 0.32$; interaction $\mathrm{M} \times \mathrm{I}, p<0.001)$. Inoculation tended to increase the abundance of Pectobacterium at the end of the second and third month after ensiling ( $p \leq 0.06)$, but not in month 1 after ensiling ( $p=0.21$; interaction $\mathrm{M} \times \mathrm{I}, p=0.03$ ). Inoculation decreased Tartumella at the end of the first month after ensiling $(p=0.04)$, but had no influence thereafter $(p \geq 0.15$; interaction $\mathrm{M} \times \mathrm{I}, p=0.01)$. 

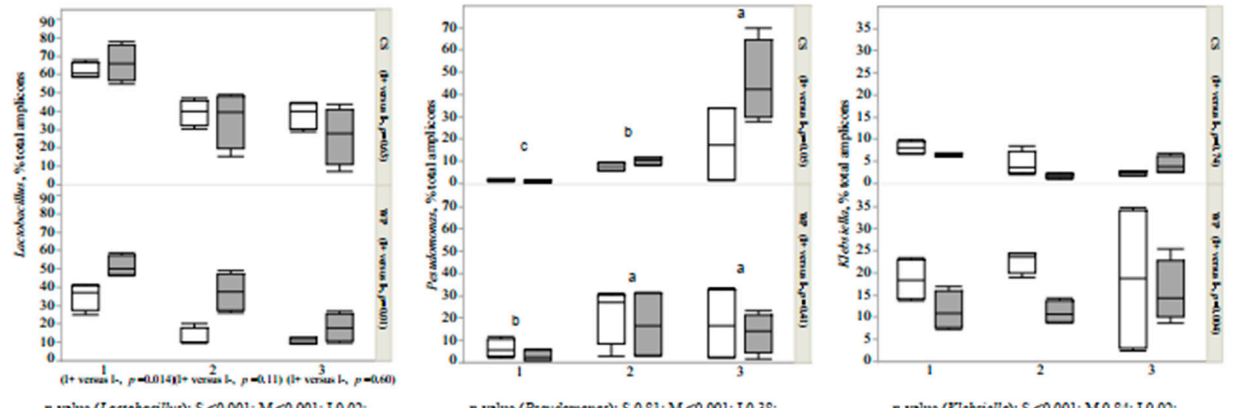

p.value (Loctobaciling): $\$<0.001: \mathrm{M}<0.001: 10.02$

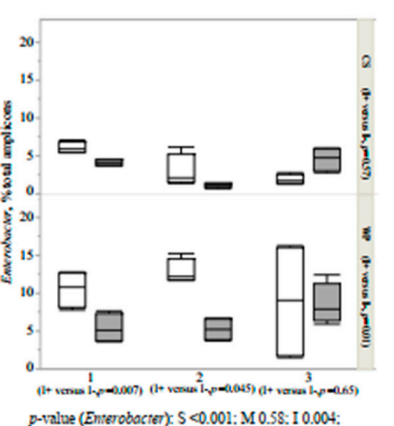

P.value (Pendiomonos): $50.81: \mathrm{M}<0.001: 10.38$ :

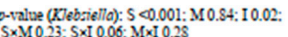
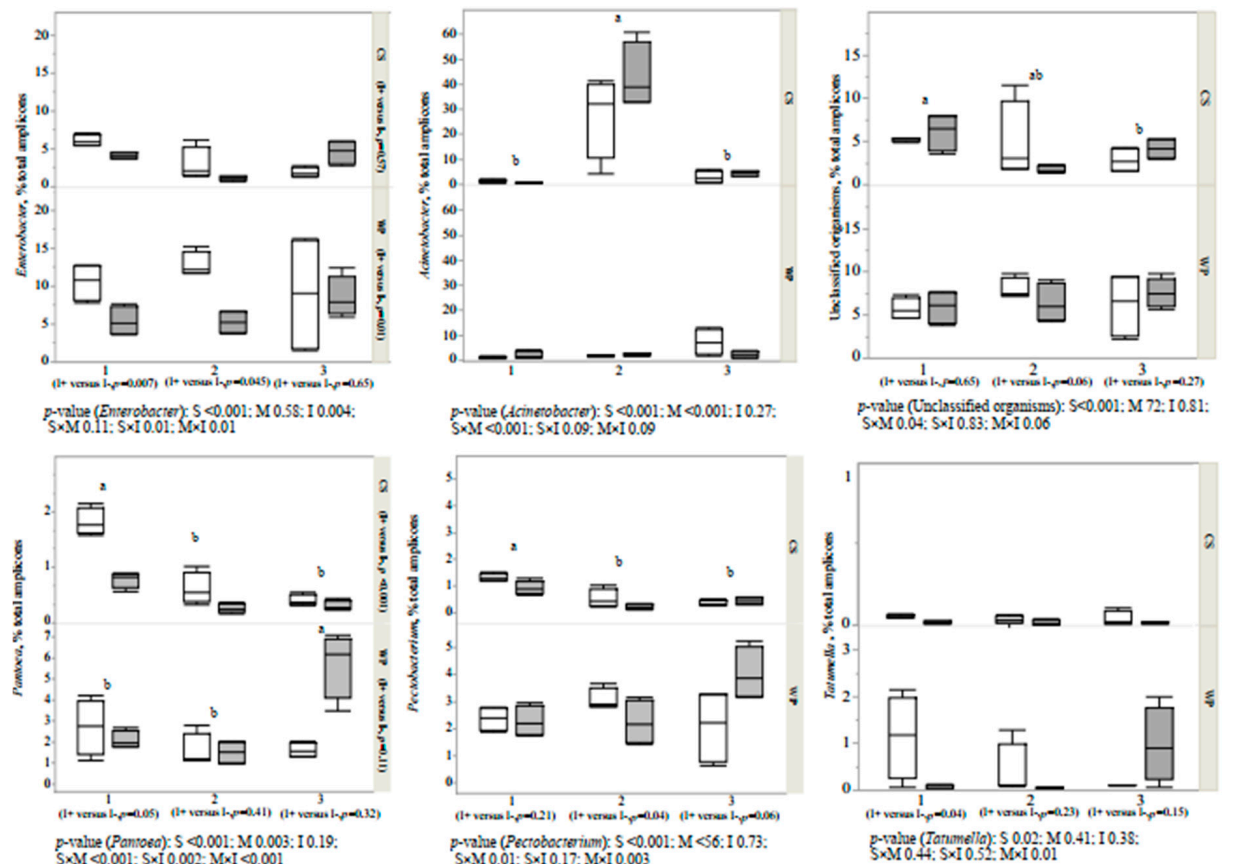

Figure 6. Effects of substrate, ensiling time, and inoculation of Lactobacillus plantarum on bacterial relative abundance $(>0.5 \%)$ in silage $(\mathrm{n}=4)$. Substrates are shown in panels. CS, sweet corn stover; $\mathrm{WP}$, sweet corn whole plant. Sampling time points (months after ensiling) are scattered along the $x$ axis. Inoculation with Lactobacillus plantarum is indicated with gray filling in the box plots. $p$ values for the following effects are provided in legends below the graph: M, Months after ensiling; $\mathrm{S}$, substrate; $\mathrm{I}-$, not inoculated; $\mathrm{I}+$, inoculated; $\mathrm{S} \times \mathrm{M}$; interaction between substrate and month; $\mathrm{S} \times \mathrm{I}$; interaction between substrate and inoculation; $\mathrm{M} \times \mathrm{I}$; interaction between month and inoculation. ${ }^{\text {adc }}$ Unlikelower case letters within a substrate panel differ $(p<0.05)$.

\section{Discussion}

High lactic acid production, low $\mathrm{pH}$, and low butyric acid concentration are key indicators of successful ensiling [11]. Lactic acid production is crucial for rapidly decreasing silage $\mathrm{pH}$, and thus inhibiting deleterious epiphytic proteolytic microorganisms such as clostridia and molds [30]. The concentration of lactic acid in CS silages in our study (about $40 \mathrm{mg} / \mathrm{g} \mathrm{DM}$ ) was comparable with that reported for CS silages of sweet corn [14] and regular corn [31]. As far as WP silage with sweet corn in our study, lactic acid content was about two times higher than WP silage of regular corn [32]. The $\mathrm{pH}$ of all the treatments evaluated in this experiment fluctuated within 3.54 and 3.68, which can be defined as adequate [11]. Butyric acid is an indicator of spoilage in silage, as butyric acid producers such as genus Clostridium can degrade lactic acid and thus increase the growth of spoilage microbes [33]. In the meta-analysis conducted by Blajman et al. [34], the mean concentration of butyric acid in corn silages was of $1.1 \mathrm{mg} / \mathrm{g} \mathrm{DM}$, which is higher than what we found in both substrates at all time points, except the WP silage at the end of the third month. Therefore, butyric acid concentration was small, and genus Clostridium were not detected in 
any of the silages. As inoculation with L. plantarum did not increase lactic acid concentration, it seems that there were enough numbers of native LAB attached to plants at harvest to produce enough lactic acid in the non-inoculated silages, although in WP silage there was a tendency to increase the abundance of the genus Lactobacillus with inoculation of L. plantarum. In summary, both substrates seemed to be successfully ensiled without inoculation, based on key indicator variables such as $\mathrm{pH}$, lactic acid, and butyric acid concentrations, and the abundance of genus Clostridium.

The initial LAB communities present in the plant material to be ensiled are important to the adequacy of fermentation and silage quality (McDonald, 1991; Lin et al., 1992b; Yang et al., 2010). There is lack of knowledge about how many lactic acid bacteria are required to start fermentation successfully. In most studies, LAB were inoculated at levels between $10^{5}$ and $10^{7} \mathrm{CFU} / \mathrm{g}$ [34]. The initial relative abundance of the Lactobacillus genus in fresh corn forages in our study $(0.41 \%)$ was comparable with previous reports [35,36]. After ensiling and with oxygen depletion, strict anaerobes begin to dominate the bacterial community [37]. In our study, genus Lactobacillus reached a relative abundance of $53.7 \%$ in silages within month 1 after ensiling, which is similar to what was reported by Xu et al. [31] but lower than what was reported by Keshri et al. [36] and Drouin et al. [32], who reported genus Lactobacillus to account for $>80 \%$ of total bacteria in corn silage. Corn silage is characterized by a succession of heterofermentative LAB such as Pediococci, Leuconostoc, and Streptococci during long storage periods [32,38]. However, this heterofermentative LAB succession was not detected in our study. Factors such as relatively high moisture [13] and $\mathrm{NH}_{4}{ }^{+}$content in sweet corn compared to regular corn could contribute to explain the relatively low LAB abundance [39-41].

In some studies, inoculation with LAB such as L. plantarum $[36,42,43]$ and L. buchneri [44] was reported to increase lactic acid concentration in corn silage. However, other studies found no effect of inoculation of corn silage with homofermentative LAB on lactic acid concentration [36,45-47]. In our study, even though the abundance of Lactobacillus was comparatively low relative to some previous studies, inoculation with L. plantarum seemed to have increased its dominance within the genus Lactobacillus, as indicated by the substantial decrease in the diversity of Lactobacillus OTUs in the inoculated silages. However, production of lactic acid was unaffected by inoculation with L. plantarum. The dominant LAB can affect silage fermentation end-products [48]. Inoculation with heterofermentative LAB can decrease lactic acid but increase acetic acid concentration [34]. In the present study, inoculation with $L$. plantarum decreased acetic acid concentration, in agreement with previous reports $[34,44,46]$. On the other hand, others have reported that acetic acid was not affected by inoculation of L. plantarum [36,42]. The concentrations of ethanol and acetic acid in sweet corn stover silage was comparable with a previous report [14]. Acetic acid inhibits yeast metabolism of lactic acid [49].

In agreement with previous findings [36,44], the major yeast product ethanol was unaffected by inoculating L. plantarum in either CS or WP silage, suggesting that inoculation with L. plantarum had no effect on yeast growth during anaerobic storage.

In both fresh WP and CS before ensiling, there was considerable abundance of aerobic and facultative anaerobic bacteria, such as genus Pseudomonas, genus Klebsiella, genus Enterobacter, genus Pantoea, genus Lactococcus, and genus Raoultella, but limited abundance of genus Lactobacillus. In a previous study conducted in Israel, the dominant bacterial genera in fresh corn whole plant were Acinetobacter, Klebsiella, Weissella, and Sphingomonas [36]. In three different locations in Iran, the epiphytic bacterial communities in fresh corn whole plant forage were dominated by the family Leuconostocaceae and genera Luconostoc and Weissella [35]. In the United States, the most abundant genera in fresh samples of whole plant corn were Flavobacterium and Chryseobacterium, belonging to the Flavobacteriales order [32]. Altogether, those three studies and ours indicate the existence of substantial variation among different regions in the world in the epiphytic bacterial community in fresh corn crops. Possibly, the succession of LAB could also be influenced by initial composition of epiphytic bacterial communities. 
Fermentation can be promoted by adding 7\% sugars to WSC-deficient silage substrates such as wheat straw [50]. This level of WSC produces good quality grass silages, as also indicated by Amer et al. [51]. The WSC content of sweet corn was much higher than this level, which likely also contribute to adequate production of lactic acid ( $>40 \mathrm{mg} / \mathrm{g}$ ). Although residual WSC can, on the one hand, induce the growth of undesirable microbes such as lactate-assimilating yeasts [34], they reflect a more efficient silage fermentation [44,52]. Interestingly, inoculating L. plantarum in WP silage preserved greater content of WSC as well as $\mathrm{CP}$ and starch compared to non-inoculated silages. Inoculating LAB in high moisture substrate for ensilage can allow for a more desirable fermentation [53]. The inoculation of WP silage with L. plantarum might be beneficial to preserve starch content, as indicated by a $14 \%$ increase in starch content caused by inoculating L. plantarum in WP silage. In the present study, WP and CS were harvested from the same field and on the same day, thus the only agronomical difference in the initial material for ensilage was the presence or absence of corn ears. It is possible that the density of attached native LAB was lower in corn ears than in CS, and that thus removing corn ears from WP increased the density of native Lactobacillus in the resulting CS. In agreement with this possibility, Lynch et al. [54] reported that native LAB attached to CS was higher in comparison with corn ears. Inoculating corn ears with two strains of L. plantarum did not affect starch content [54]. However, unlike our results, inoculation of corn ear silage with L. plantarum did not affect or even decrease LAB counts compared to the non-inoculated control [54].

Fiber seemed to be degraded in CS silage in the third month after ensiling, as the NDF content of CS silage was $22 \%$ lower after the third month of ensilage compared to the second month. On the other hand, fiber seemed to be unaffected in WP silage. After WSC are depleted by fermentation during ensiling, fiber may be partially digested and fermented as an alternative substrate [50]. It is possible that the increase observed in acetic acid concentration in CS silage at the end of the second month after ensiling could be a result of fermentation of fiber. The idea of fiber serving as a source of fermentable sugars, however, is difficult to reconcile with the fact that NDF and ADF contents in WP silage were unaffected, even numerically, considering that WSC were lower in CS silage than in WP silage.

Members in genus Acinetobacter are aerobic bacteria reported to be present in incompletely tight silage bunkers [55] or during aerobic exposure [56]. Genus Acinetobacter increased at the end of the second month after ensiling in CS silage, which might imply incomplete anaerobic conditions. Incomplete anaerobic conditions can also allow for yeast proliferation and ethanol production, in agreement with the observed increase in ethanol in the third month after ensiling in CS silages. We speculate that fiber might have been degraded in microaerobic pockets during the third month after ensiling, as suggested by the simultaneous decrease in fiber content in the CS silage and increase in Acinetobacter abundance. It has been reported that heterofermentative lactic acid bacteria produces the most acetate during the process of long-term preservation [32]. However, that was not our case. Our results showed fiber degradation and increased acetic acid in CS silage during the third month after ensiling, indicating the acetic acid may have been produced as a result of fibrolytic activity. Acinetobacter has been shown to degrade cellulose and hemicellulose to monomers such as glucose and xylose [57,58]; if that was the case, the presumably microaerophilic environment may have still allowed for some acetic acid formation. Genus Pseudomonas, another aerobic bacterium found in silage in the current study, can use acetic acid as a carbon source [59]. The increase in genus Pseudomonas during the ensilage process might help explain the decline in acetic acid content during the third month of ensilage.

\section{Conclusions}

Successful ensiling could be achieved in both CS and WP silage with or without inoculation of L. plantarum. It is thought that the lack of major effects of inoculation with L. plantarum was due to the presence of enough native LAB in the ensiled corn plants. However, greater preservation of starch in WP silage could be achieved by inoculating 
L. plantarum. Inoculation with $L$. plantarum could then help improving the nutritional quality of WP silage for ruminants with high energy requirements, such as dairy cows in early lactation. The effects of inoculation with L. plantarum on the aerobic stability of these two ensiled substrates remain to be investigated.

Author Contributions: Conceptualization, Z.O. and Z.-L.T.; methodology, X.-L.Z. and Y.-Q.Z.; investigation, Z.-Y.M. and X.-F.H.; data curation, Z.-Y.M. and X.-F.H.; writing—original draft preparation, Z.-Y.M. and X.-L.Z.; writing-review and editing, Z.-Y.M. and E.U.; project administration, X.-F.H. All authors have read and agreed to the published version of the manuscript.

Funding: This work was supported by the Strategic Priority Research Program of the Chinese Academy of Sciences (Grant No. XDA26040304), the Hunan Innovation Province Project (Grants No. 2020NK2049), and the Science and Technology Service Network Initiative of the Chinese Academy of Sciences (Grant No. KFJ-EW-STS-054) for the joint financial support provided.

Institutional Review Board Statement: Not applicable.

Informed Consent Statement: Not applicable.

Data Availability Statement: The raw sequence for this study can be found in the Sequence Read Archive of NCBI (https: / / www.ncbi.nlm.nih.gov / bioproject/PRJNA556529 (accessed on 4 January 2022).

Conflicts of Interest: The authors declare no conflict of interest. The funders had no role in the design of the study; in the collection, analyses, or interpretation of data; in the writing of the manuscript, or in the decision to publish the results.

\section{References}

1. Coşkun, M.B.; Yalçın, İ.; Özarslan, C. Physical properties of sweet corn seed (Zea mays saccharata Sturt.). J. Food Eng. 2006, 74, 523-528. [CrossRef]

2. Azanza, F.; Bar-Zur, A.; Juvik, J.A. Variation in sweet corn kernel characteristics associated with stand establishment and eating quality. Euphytica 1996, 87, 7-18. [CrossRef]

3. Lazcano, C.; Revilla, P.; Malvar, R.A.; Dominguez, J. Yield and fruit quality of four sweet corn hybrids (Zea mays) under conventional and integrated fertilization with vermicompost. J. Sci. Food Agric. 2011, 91, 1244-1253. [CrossRef] [PubMed]

4. FAO. FAOStat: Food and Agriculture Data. Available online: http://www.fao.org/faostat/en/\#data/QC (accessed on 12 January 2021).

5. Li, K.; Huang, C. Current production status, problem and countermeasure on sweet corn industry in China. Sugar Crops China 2021, 43, 67-71. (In Chinese) [CrossRef]

6. Olsen, J.K.; McMahon, C.R.; Hammer, G.L. Prediction of sweet corn phenology in subtropical environments. Agron. J. 1993, 85, 410-415. [CrossRef]

7. Zhang, J.G.; Liu, Q.H.; Yang, F.Y. The chemical composition and ensiling characteristics of sweet corn processing by-products. Adv. Mater. Res. 2011, 236-238, 305-308. [CrossRef]

8. Barros-Ríos, J.; Romaní, A.; Garrote, G.; Ordas, B. Biomass, sugar, and bioethanol potential of sweet corn. Glob. Chang. Biol. Bioenergy 2015, 7, 153-160. [CrossRef]

9. Shinners, K.J.; Binversie, B.N. Whole-Plant Corn Harvesting for Biomass: Comparision of Single-Pass and Ultiple-Pass Harvest Systems; Paper number 036089; ASAE Annual Meeting, 2003; American Society of Agricultural and Biological Engineers: St. Joseph, MI, USA, 2003.

10. Cui, T. Finishing effects comparison trials between whole corn silage and corn silage without ear. J. Yellow Cattle Sci. 2002, 3 . (In Chinese)

11. Muck, R.E. Factors Influencing Silage Quality and Their Implications for Management. J. Dairy Sci. 1988, 71, 2992-3002. [CrossRef]

12. Yahaya, M.S.; Kawai, M.; Takahashi, J.; Matsuoka, S. The effects of different moisture content and ensiling time on silo degradation of structural carbohydrate of orchardgrass. Asian Austral. J. Anim. 2002, 15, 213-217. [CrossRef]

13. Kurle, J.E.; Sheaffer, C.C.; Crookston, R.K.; Peterson, R.H.; Chester-Jones, H.; Lueschen, W.E. Popcorn, Sweet Corn, and Sorghum as Alternative Silage Crops. J. Prod. Agric. 2013, 4, 432-436. [CrossRef]

14. Zhou, X.; Ouyang, Z.; Zhang, X.; Wei, Y.; Tang, S.; Ma, Z.; Tan, Z.; Zhu, N.; Teklebrhan, T.; Han, X. Sweet corn stalk treated with saccharomyces cerevisiae alone or in combination with Lactobacillus plantarum: Nutritional composition, fermentation traits and aerobic stability. Animals 2019, 9, 598. [CrossRef]

15. Parvin, S.; Wang, C.; Li, Y.; Nishino, N. Effects of inoculation with lactic acid bacteria on the bacterial communities of Italian ryegrass, whole crop maize, guinea grass and rhodes grass silages. Anim. Feed Sci. Technol. 2010, 160, 160-166. [CrossRef]

16. Fijałkowska, M.; Przemieniecki, S.W.; Purwin, C.; Lipiński, K.; Kurowski, T.P.; Karwowska, A. The effect of an additive containing three Lactobacillus species on the fermentation pattern and microbiological status of silage. J. Sci. Food Agric. 2020, 100, 1174-1184 [CrossRef] 
17. Bernardes, T.F.; Gervasio, J.; De Morais, G.; Casagrande, D.R. Technical note: A comparison of methods to determine $\mathrm{pH}$ in silages. J. Dairy Sci. 2019, 102, 9039-9042. [CrossRef]

18. Playne, M.J. Determination of ethanol, volatile fatty acids, lactic and succinic acids in fermentation liquids by gas chromatography. J. Sci. Food Agric. 1985, 36, 638-644. [CrossRef]

19. AOAC. Official Method of Analysis, 15th ed.; AOAC: Washington, DC, USA, 1990.

20. Van Soest, P.J.; Robertson, J.B.; Lewis, B.A. Methods for dietary fiber, neutral detergent fiber, and nonstarch polysaccharides in relation to animal nutrition. J. Dairy Sci. 1991, 74, 3583-3597. [CrossRef]

21. Karthner, R.J.; Theurer, B. Comparison of hydrolysis methods used in feed, digesta, and fecal starch analysis. J. Agric. Food Chem. 1981, 29, 8-11. [CrossRef] [PubMed]

22. Zahiroddini, H.; Baah, J.; Absalom, W.; Mcallister, T.A. Effect of an inoculant and hydrolytic enzymes on fermentation and nutritive value of whole crop barley silage. Anim. Feed Sci. Technol. 2004, 117, 317-330. [CrossRef]

23. Denman, S.E.; McSweeney, C.S. Development of a real-time PCR assay for monitoring anaerobic fungal and cellulolytic bacterial populations within the rumen. FEMS Microbiol. Ecol. 2006, 58, 572-582. [CrossRef] [PubMed]

24. Jiao, J.; Wang, P.; He, Z.; Tang, S.; Zhou, C.; Han, X.; Wang, M.; Wu, D.; Kang, J.; Tan, Z. In vitro evaluation on neutral detergent fiber and cellulose digestion by post-ruminal microorganisms in goats. J. Sci. Food Agric. 2014, 94, 1745-1752. [CrossRef] [PubMed]

25. Inceoglu, O.; Al-Soud, W.A.; Salles, J.F.; Semenov, A.V.; van Elsas, J.D. Comparative analysis of bacterial communities in a potato field as determined by pyrosequencing. PLOS ONE 2011, 6, e23321. [CrossRef]

26. Schloss, P.D.; Westcott, S.L.; Ryabin, T.; Hall, J.R.; Hartmann, M.; Hollister, E.B.; Lesniewski, R.A.; Oakley, B.B.; Parks, D.H.; Robinson, C.J.; et al. Introducing mothur: Open-source, platform-independent, community-supported software for describing and comparing microbial communities. Appl. Environ. Microbiol. 2009, 75, 7537-7541. [CrossRef]

27. Kozich, J.J.; Westcott, S.L.; Baxter, N.T.; Highlander, S.K.; Schloss, P.D. Development of a dual-index sequencing strategy and curation pipeline for analyzing amplicon sequence data on the MiSeq Illumina sequencing platform. Appl. Environ. Microbiol. 2013, 79, 5112-5120. [CrossRef]

28. Wang, Q.; Garrity, G.M.; Tiedje, J.M.; Cole, J.R. Naive Bayesian classifier for rapid assignment of rRNA sequences into the new bacterial taxonomy. Appl. Environ. Microbiol. 2007, 73, 5261-5267. [CrossRef]

29. Quast, C.; Pruesse, E.; Yilmaz, P.; Gerken, J.; Schweer, T.; Yarza, P.; Peplies, J.; Glockner, F.O. The SILVA ribosomal RNA gene database project: Improved data processing and web-based tools. Nucleic Acids Res. 2013, 41, D590-D596. [CrossRef]

30. Halim, R.A.; Aimera, F.S.; Noraniza, M.; Abdullah, N.; Rahman, N.A. Changes in Water Soluble Carbohydrate for Corn Silage Treated with Bacterial Cultures at Different Fermentation Durations; Malaysian Society of Animal Production: Sarawak, Malaysia, 2014.

31. Xu, Z.; Zhang, S.; Zhang, R.; Li, S.; Kong, J. The changes in dominant lactic acid bacteria and their metabolites during corn stover ensiling. J. Appl. Microbiol. 2018, 125, 675-685. [CrossRef]

32. Drouin, P.; Tremblay, J.; Chaucheyras-Durand, F. Dynamic succession of microbiota during ensiling of whole plant corn following inoculation with Lactobacillus buchneri and Lactobacillus hilgardii alone or in combination. Microorganisms 2019, 7, 595. [CrossRef]

33. Dunière, L.; Sindou, J.; Chaucheyras-Durand, F.; Chevallier, I.; Thévenot-Sergentet, D. Silage processing and strategies to prevent persistence of undesirable microorganisms. Anim. Feed Sci. Technol. 2013, 182, 1-15. [CrossRef]

34. Blajman, J.E.; Paez, R.B.; Vinderola, C.G.; Lingua, M.S.; Signorini, M.L. A meta-analysis on the effectiveness of homofermentative and heterofermentative lactic acid bacteria for corn silage. J. Appl. Microbiol. 2018, 125, 1655-1669. [CrossRef] [PubMed]

35. Gharechahi, J.; Kharazian, Z.A.; Sarikhan, S.; Jouzani, G.S.; Aghdasi, M.; Hosseini Salekdeh, G. The dynamics of the bacterial communities developed in maize silage. Microb. Biotechnol. 2017, 10, 1663-1676. [CrossRef] [PubMed]

36. Keshri, J.; Chen, Y.; Pinto, R.; Kroupitski, Y.; Weinberg, Z.G.; Sela, S. Microbiome dynamics during ensiling of corn with and without Lactobacillus plantarum inoculant. Appl. Microbiol. Biotechnol. 2018, 102, 4025-4037. [CrossRef] [PubMed]

37. Lin, C.; Bolsen, K.K.; Brent, B.E.; Hart, R.A.; Dickerson, J.T.; Feyerherm, A.M.; Aimutis, W.R. Epiphytic microflora on alfalfa and whole-plant corn. J. Dairy Sci. 1992, 75, 2484-2493. [CrossRef]

38. Cai, Y.; Benno, Y.; Ogawa, M.; Ohmomo, S.; Kumai, S.; Nakase, T. Influence of Lactobacillus spp. from An inoculant and of Weissella and Leuconostoc spp. from forage crops on silage fermentation. Appl. Environ. Microbiol. 1998, 64, 2982-2987. [CrossRef]

39. Kung, L.J.; Robinson, J.R.; Ranjit, N.K.; Chen, J.H.; Golt, C.M.; Pesek, J.D. Microbial populations, fermentation end-products, and aerobic stability of corn silage treated with ammonia or a propionic acid-based preservative. J. Dairy Sci. 2000, 83, 1479-1486. [CrossRef]

40. Der Bedrosian, M.C.; Nestor, K.J.; Kung, L.J. The effects of hybrid, maturity, and length of storage on the composition and nutritive value of corn silage. J. Dairy Sci. 2012, 95, 5115-5126. [CrossRef]

41. Ranjit, N.K.; Kung, L.J. The effect of Lactobacillus buchneri, Lactobacillus plantarum, or a chemical preservative on the fermentation and aerobic stability of corn silage. J. Dairy Sci. 2000, 83, 526-535. [CrossRef]

42. Addah, W.; Baah, J.; Groenewegen, P.; Okine, E.K.; McAllister, T.A. Comparison of the fermentation characteristics, aerobic stability and nutritive value of barley and corn silages ensiled with or without a mixed bacterial inoculant. Can. J. Anim. Sci. 2011, 91, 133-146. [CrossRef]

43. Driehuis, F.; Oude Elferink, S.J.W.H.; Van Wikselaar, P.G. Fermentation characteristics and aerobic stability of grass silage inoculated with Lactobacillus buchneri, with or without homofermentative lactic acid bacteria. Grass Forage Sci. 2001, 56, 330-343. [CrossRef] 
44. Arriola, K.G.; Kim, S.C.; Adesogan, A.T. Effect of applying inoculants with heterolactic or homolactic and heterolactic bacteria on the fermentation and quality of corn silage. J. Dairy Sci. 2011, 94, 1511-1516. [CrossRef]

45. Aksu, T.; Baytok, E.; Karslı, M.A.; Muruz, H. Effects of formic acid, molasses and inoculant additives on corn silage composition, organic matter digestibility and microbial protein synthesis in sheep. Small Rumin. Res. 2006, 61, 29-33. [CrossRef]

46. Filya, I.; Sucu, E.; Karabulut, A. The effects of Propionibacterium acidipropionici and Lactobacillus plantarum, applied at ensiling, on the fermentation and aerobic stability of low dry matter corn and sorghum silages. J. Ind. Microbiol. Biotechnol. 2006, 33, 353-358. [CrossRef] [PubMed]

47. Jiang, F.; Cheng, H.; Liu, D.; Wei, C.; An, W.; Wang, Y.; Sun, H.; Song, E. Treatment of Whole-Plant Corn Silage With Lactic Acid Bacteria and Organic Acid Enhances Quality by Elevating Acid Content, Reducing pH, and Inhibiting Undesirable Microorganisms. Front. Microbiol. 2020, 11, 593088. [CrossRef] [PubMed]

48. Mogodiniyai Kasmaei, K.; Rustas, B.O.; Spörndly, R.; Udén, P. Prediction models of silage fermentation products on crop composition under strict anaerobic conditions: A meta-analysis. J. Dairy Sci. 2013, 96, 6644-6649. [CrossRef]

49. Lindgren, S.E.; Dobrogosz, W.J. Antagonistic activities of lactic acid bacteria in food and feed fermentations. FEMS Microbiol. Rev. 1990, 7, 149-163. [CrossRef] [PubMed]

50. Yang, H.Y.; Wang, X.F.; Liu, J.B.; Gao, L.J.; Ishii, M.; Igarashi, Y.; Cui, Z.J. Effects of water-soluble carbohydrate content on silage fermentation of wheat straw. J. Biosci. Bioeng. 2006, 101, 232-237. [CrossRef] [PubMed]

51. Amer, S.; Hassanat, F.; Berthiaume, R.; Seguin, P.; Mustafa, A.F. Effects of water soluble carbohydrate content on ensiling characteristics, chemical composition and in vitro gas production of forage millet and forage sorghum silages. Anim. Feed Sci. Technol. 2012, 177, 23-29. [CrossRef]

52. Przemieniecki, S.W.; Purwin, C.; Mastalerz, J.; Borsuk, M.; Lipiński, K.; Kurowski, T. Biostimulating effect of L-tryptophan on the yield and chemical and microbiological quality of perennial ryegrass (Lolium perenne) herbage and silage for ruminant. J. Sci. Food Agric. 2020, 101, 3969-3974. [CrossRef]

53. Schaefer, D.M.; Brotz, P.G.; Arp, S.C.; Cook, D.K. Inoculation of corn silage and high-moisture corn with lactic acid bacteria and its effects on the subsequent fermentations and on feedlot performance of beef steers. Anim. Feed Sci. Technol. 1989, 25, 23-38. [CrossRef]

54. Lynch, J.P.; O'Kiely, P.; Waters, S.M.; Doyle, E.M. Conservation characteristics of corn ears and stover ensiled with the addition of Lactobacillus plantarum MTD-1, Lactobacillus plantarum 30114, or Lactobacillus buchneri 11A44. J. Dairy Sci. 2012, 95, 2070-2080. [CrossRef]

55. Li, Y.; Nishino, N. Monitoring the bacterial community of maize silage stored in a bunker silo inoculated with Enterococcus faecium, Lactobacillus plantarum and Lactobacillus buchneri. J. Appl. Microbiol. 2011, 110, 1561-1570. [CrossRef] [PubMed]

56. Liu, Q.H.; Shao, T.; Zhang, J.G. Determination of aerobic deterioration of corn stalk silage caused by aerobic bacteria. Anim Feed Sci. Technol. 2013, 183, 124-131. [CrossRef]

57. Lo, Y.C.; Lu, W.C.; Chen, C.Y.; Chen, W.M.; Chang, J.S. Characterization and high-level production of xylanase from an indigenous cellulolytic bacterium Acinetobacter junii F6-02 from southern Taiwan soil. Biochem. Eng. J. 2010, 53, 77-84. [CrossRef]

58. Pourramezan, Z.; Ghezelbash, G.R.; Romani, B.; Ziaei, S.; Hedayatkhah, A. Screening and identification of newly isolated cellulose-degrading bacteria from the gut of xylophagous termite Microcerotermes diversus (Silvestri). Microbiology 2012, 81, 736-742. [CrossRef]

59. Kornberg, H.L.; Krebs, H.A. Synthesis of cell constituents from C2-units by a modified tricarboxylic acid cycle. Nature 1957, 179, 988-991. [CrossRef] 